\title{
Effects of road traffic on photosynthetic pigments and heavy metal accumulation in tree species of Kumasi Metropolis, Ghana
}

\author{
Ufere N. Uka ${ }^{1}$ (1) $\cdot$ Ebenezer J. D. Belford ${ }^{2} \cdot$ Florence A. Elebe $^{1}$
}

Received: 30 August 2020 / Accepted: 21 December 2020 / Published online: 13 January 2021

(C) The Author(s) 2021 OPEN

\begin{abstract}
This study was undertaken to examine changes in the content of pigments and accumulation of metals from vehicular pollution in selected species of roadside trees under vehicular pollution. A major arterial road with heavy vehicle emissions in the Kumasi Metropolis was designated as the polluted site, while Kwame Nkrumah University of Science and Technology Campus was designated as the control site. Four tree species (Terminalia catappa, Mangifera indica, Ficus platyphylla and Polyalthia longifolia) selected for the study were well distributed and abundant in the polluted and control sites. Photosynthetic pigments and levels of heavy metals ( $\mathrm{Pb}, \mathrm{Cu}, \mathrm{Cd}$ and zinc) were assessed in their leaves. Chlorophyll and carotenoid contents were determined by absorption spectrometry, while the metal accumulation index (MAI) was used to determine the total metal accumulation capacity of the tree species. We observed a reduction in photosynthetic pigments in the leaf samples from the polluted site. Ficus platyphylla had the maximum reduction in total chlorophyll (49.34\%), whereas Terminalia catappa recorded the lowest reduction (33.88\%). Similarly, the largest decrease (31.58\%) of carotenoid content was found in Terminalia catappa trees and the lowest in Polyalthia longifolia (16.67\%). The Polyalthia longifolia, Ficus platyphylla and Terminalia catappa leaf samples collected at the polluted site recorded a higher ratio of chlorophyll a/b. Heavy metal ( $\mathrm{Cu}, \mathrm{Pb}, \mathrm{Zn}$ and $\mathrm{Cd}$ ) accumulation in leaf samples was higher in the polluted site than in the control, as expected. The highest metal MAI value was recorded in Mangifera indica (5.35) followed by Polyalthia longifolia with 4.30. The findings from this study specifically demonstrate that air contamination induced by vehicles decreases the level of photosynthetic pigments in trees subjected to roadside emissions. It is clear that both chlorophyll a/b and chlorophyll/carotenoid ratios will act as very useful stress-level markers. Elevated heavy metal levels in the tree species along arterial roadsides indicate that they serve as heavy metals sink. The change in MAI resulting from different pollution burden is an indication that the removal capabilities of the tree species differ from each other. We therefore suggest $M$. indica and $P$. longifolia as potential species to be used in air pollution reduction plans in the city.
\end{abstract}

Keywords Heavy metal · Photosynthetic pigment · Urban trees physiology · Vehicular air pollution

\section{Background}

Because of the rapid economic growth, social linkage and spread activities, transportation is now the pillar of accessibility systems. It is a decisive factor of economic growth and social interactions in most countries. Regrettably, the antagonistic consequences of transportation exhibit an overbearing influence on the natural and human environment. At the regional and global levels, vehicular emissions have been considered the major source of air pollution in the cities. Motor vehicles emit significant amounts of $\mathrm{CO}$, SOx, NOx, VOCs, HC, NOx, Cu, Cd, Co, $\mathrm{Cr}$ and $\mathrm{Pb}$, responsible for $60-70 \%$ of urban air pollution $[15,18,49]$. Most of these pollutants found in the cities can be removed from

$\triangle$ Ufere N. Uka, ufere.uka@ebsu.edu.ng | ${ }^{1}$ Department of Applied Biology, Ebonyi State University, Abakaliki, Nigeria. ${ }^{2}$ Department of Theoretical and Applied Biology, Kwame Nkrumah University of Science and Technology, Kumasi, Ghana. 
air by plants through absorption, adsorption, detoxification, aggregation and additionally metabolization to the urban population [61]. Once inside the leaves, these contaminants contribute to a decrease in the concentration of chlorophyll pigments that directly influence the plants productivity [29]. Agyemang-Bonsu et al. [4] calculated emissions of ten vehicles pollutants and reported that in Kumasi Metropolis, all of which increased progressively over five years due to increase of autopollution.

In polluted area, plants show several changes in morphology, physiology and biochemistry of leaves $[21,23$, 56]. Plant leaves have considerable ecological significance as heavy metals pollution biomonitors [81]. Trees in urban areas participate in the filtration of surrounding air through heavy metal removal and adsorbing of particulate matter $[19,44]$. Researchers have carried out experiments on the effects of air pollution cause by vehicles on plant biochemistry, anatomy and physiology $[26,64,82]$, in the different parts of the world.

In accordance with [48], the analysis of chemical composition variations in plants from clean and contaminated habitats is aimed at determining the impact of sources of contamination. Analysis of concentrations of heavy metals in urban plants will lead to the natural ecosystem management and provide objective advice for policy decisions on urban greening species [25].

Many plants may be used as traffic-based air quality biomonitors $[53,57,72,73]$. In regions of heavy traffic, such as urban centers', heavy metal emission is considered to be reasonably high [11-14, 70-72, 84]. Plants are also used as biomonitors to track the accumulation of heavy metals. The tree leaves were widely used as indicators of atmospheric pollution $[35,58]$. Therefore, the usage of plant leaves as heavy metal pollution biomonitors is of considerable environmental significance $[8,43,88]$. Plants are essential component of the environment in the reduction of pollution levels [9] and can also be utilized as biological indicators of air pollution [23]. The exhibition of different noticeable changes in relation to the pollution level is an indicator of leaf sensitivity to air pollution [32]. Most roadside plant studies were performed in other countries, such as Turkey [36], India [63], Thailand [79], China [90] and Nepal [91]. Little to no research on tropical city of Kumasi, Ghana's fully grown roadside tree plants has been carried out. In order to support planning and management of urban trees in the city of Kumasi, Ghana, we evaluated the capabilities of air pollution removal of four main tree species in the city, while evaluating their tolerance to high pollution concentrations.

\section{Methods}

\subsection{Study area}

Kumasi is the capital of Ashanti region and is located in South Central Ghana. Kumasi is situated between latitude $6.35^{\circ}-6.40^{\circ}$ and longitude $1.30^{\circ}-1.35^{\circ}$ and is subdivided into ten Sub-Metropolis. The city is located in domain of the tropical rain forest with a bi-modal pattern of rainfall. The average temperature is $26.4^{\circ} \mathrm{C}$ [42], and average annual rainfall is $1250 \mathrm{~mm}$ [52]. Kumasi is Ghana's second largest and fastest growing town with an average population growth rate of $5.4 \%$. It is a key transit point for travelers from inside and outside Ghana and hosts West African free market [1]. Two sampling sites [Offinso road and Kwame Nkrumah University of Science and Technology (KNUST) Campus] in Kumasi Metropolis were selected for this study. Offinso road, in Suame Sub-Metro, is situated between $6^{\circ} 43^{\prime} 52.65^{\prime \prime} \mathrm{N}$ latitude and $1^{\circ} 37^{\prime} 40.74^{\prime \prime} \mathrm{W}$. It has a road length of $6.1 \mathrm{~km}$ and average daily traffic per lane of 24,269 vehicles and thus undergoes severe traffic congestion. Therefore, traffic is the main source of air pollution in this site. In view of these pollution sources, Offinso road was chosen as the polluted site for study. Conversely, KNUST campus was selected as a control site for having an area of about seven square miles in a suburban area with low local traffic. KNUST campus in Oforikrom is situated between $6^{\circ} 41^{\prime} 5.67^{\prime} \mathrm{N}$ latitude and $1^{\circ} 34^{\prime} 13.87^{\prime} \mathrm{W}$ longitudes.

\subsection{Air quality monitoring in the sampling sites}

The $\mathrm{SO}_{2}, \mathrm{NO}_{2}, \mathrm{CO}$ and VOC concentrations as well as temperature and relative humidity were measured at the sample sites using the Aeroqual Series 500 (S500) gas detection device (Aeroqual Limited, Auckland, New Zealand). For each site, the surrounding air quality was monitored for 6 days in one week, from 7 am to $3 \mathrm{pm}$.

\subsection{Selection of tree species}

A survey of trees frequency and density was carried out with a view to define the dominant species in the study site. Mangifera indica L, Polyalthia longifolia (Sonn.) Thw, Terminalia cattapa $\mathrm{L}$ and Ficus platyphylla Del which are in abundance and well spread in the roadsides were selected for the study. 


\subsection{Terminalia catappa L.}

Terminalia catappa belongs to the family Combretaceae. It is a tall, obvious semi-deciduous tree that grows best in tropical climate. T. catappa is an erect tree reaching 15-25 $\mathrm{m}$ tall, with maximum diameter of 1-1.5 $\mathrm{m}$ and frequently buttressed base. The tree throws a substantial shade that is valuable in greenery enclosures, schools or urban zones. Terminalia catappa quick development makes the tree important as an ornamental species. It is used as natural medicine and water conditioner http:// tropical.theferns.info/viewtropical.php?id=Terminalia +catappa

\subsection{Mangifera indica $\mathrm{L}$.}

Mangifera indica is grouped in the family Anacardiaceae. It is an extensive evergreen tree reaching up to $20 \mathrm{~m}$ tall with a dull green, umbrella-formed column. The different parts of the plant are used as an antiseptic, laxative, diuretic and laxative product. (http://apps.worldagroforestry.org/treed b/AFTPDFS/Mangifera_indica.PDF).

\subsection{Ficus platyphylla Del}

Ficus platyphylla belongs to the family Moraceaea. It is a deciduous tree 10-25 $\mathrm{m}$ tall and column spreading. The leaves are large and stiff, long and oval, $15-26 \mathrm{~cm}$ long, 10-20 cm across, edge wavy, tip blunted or pointed. Latex harvested from the tree is used as a base for chewing gum. Bark decoction is sometimes used in the treatment of leprosy and stomach pins. A decoction of the tips leafy branch is an antidote to arrow poisoning (http://tropical.theferns. info/viewtropical.php?id=Ficus+platyphylla).

\subsection{Polyalthia longifolia (Sonn.) Thw.}

Polyalthia longifolia belongs to the family Annonaceae. It is a tall nice looking, evergreen tree with a funnel-shaped column. Flowers are yellowish green, in fascicles or short umbels from the axils of fallen leaves; petals are subequal, straight, spreading, decreasing to a point. Leaves are $\mathbf{7}-20 \mathrm{~cm}$ long, lanceolate with wavy edges. The leaf decoction is used in the treatment of fever [27].

\subsection{Sample collection}

Twenty (20) fully developed leaves were collected per specimen from each of the four tree species (three individuals per species) making a total sample size of 240 leaves per sampling site. Leaves were obtained from all sides of the crown and pooled for a representative sample of each tree. The harvested leaves were placed in self-sealing black polythene bags labeled accordingly. They were placed in a polystyrene box containing ice and sent to the laboratory for further analysis. Samples for pigment quantification were stored at $-40{ }^{\circ} \mathrm{C}$ in a deep freezer. The quantification of chlorophyll $a$, chlorophyll $b$, total chlorophyll and carotenoid of the leaf samples were carried out within $24 \mathrm{~h}$ of their harvesting.

\subsection{Estimation of chlorophyll and carotenoid contents}

The spectrophotometric method by [6] was used in chlorophyll and carotenoid content determinations. Leaf samples $(3 \mathrm{~g})$ were placed and homogenized in $10 \mathrm{ml}$ of $80 \%$ acetone solution using mortar and pestle for $15 \mathrm{~min}$. The homogenate was transferred to another test tube and centrifuged at $2500 \mathrm{rpm}$ for $3 \mathrm{~min}$. The supernatant was transferred with a pipette to a cuvette, and the absorbance readings were taken against a blank using CECIL 8000 UV-Visible spectrophotometer at wavelength $645 \mathrm{~nm}, 663 \mathrm{~nm}$ and $480 \mathrm{~nm}$.

The amount of chlorophyll and carotenoid was measured as follows:-

Chlorophyll $a=12.7\left(A_{.663}\right)-2.69\left(A_{.645}\right) \times V / 1000 \times W \mathrm{mg} / \mathrm{g}$

Chlorophyll $b=22.9\left(A_{.645}\right)-4.68\left(A_{.663}\right) \times V / 1000 \times W \mathrm{mg} / \mathrm{g}$

Total chlorophyll $=20.2\left(A_{645}\right)-8.02\left(A_{663}\right) \times V / 1000 \times W$

Carotenoids $=A 480+11.4(A .663)-6.38(A .645 \mathrm{~nm}) \times V / 1000 \times W$

where $A=$ extract absorbance, $V=$ total chlorophyll solution volume $(\mathrm{ml})$ and $W=$ tissue extract weight $(\mathrm{g})$.

\subsection{Heavy metal analysis}

Leaf samples for heavy metal determination were washed thoroughly with distilled water and dried overnight in an oven at $40^{\circ} \mathrm{C}$ for heavy metal analysis. In total, $0.25 \mathrm{~g}$ was digested wet at $120^{\circ} \mathrm{C}$ in $\mathrm{HNO}_{3}$ and then diluted with deionized water to $25 \mathrm{~mL}$ [33]. The residue was transferred after digestion to a 100-mL volumetric flask and was made up to the mark using distilled water. For reference, a blank digestion solution was made. For the purpose of calibration, a standardized solution for each heavy metal under study was prepared. Heavy metal ( $\mathrm{Pb}, \mathrm{Cu}, \mathrm{Cd}$ and $\mathrm{Zn}$ ) concentrations on the leaf samples were determined by the use of atomic absorption spectrophotometer (model AA240FS). Pb, Cu, Cd and Zn hollow cathode lamps at specific wave lengths were used. All the samples were analyzed in triplicates. 


\subsection{Metal accumulation index (MAI)}

To evaluate the general metal deposition on the tree species, metal accumulation index (MAI) was adopted by using the formula below.

$\mathrm{MAI}=(1 / N)+\sum_{j=1}^{N} l j$

where $N$ is the total number of metals analyzed, $l j=x / d_{x}$ is the subindex for variable $j$, obtained by dividing the mean value $(x)$ of each metal by its standard deviation $\left(d_{x}\right)[40]$.

\subsection{Statistical analysis}

The data generated were subjected to descriptive statistics (mean and standard error), and independent $t$ test was used to evaluate the changes in photosynthetic contents and heavy metal levels in the leaves of the studied tree species among the observational sites. Correlations among different metal concentrations and metal and pigment variables were analyzed by bivariate correlation test with Pearson's correlation coefficient and two-tailed test of significance parameters at a significance level $p \leq 0.05$ and 0.001 using SPSS 23 software.

Percentage variations were calculated using the formula used by [7]

Percentage variation $(\%)=C-P / C * 100$

$C=$ mean value for leaf samples of control site; $P=$ mean value for leaf samples of polluted site.

\section{Results}

The temperature of the polluted sites was $2.17 \%$ higher in comparison with the control, while relative humidity of the control site was $1.70 \%$ higher than the polluted site. Carbon monoxide concentration (6.68 ppm) was $87.28 \%$ higher at the polluted site as comparing to control site. The $\mathrm{SO}_{2}$ concentration $(0.19 \mathrm{ppm})$ was also recorded at the polluted sites, which was $63.16 \%$ higher than the control site. An elevated $\mathrm{NO}_{2}$ concentration
(0.09 ppm) was also recorded at the polluted site and was $33.33 \%$ higher as compared to control site (Table 1).

\subsection{Photosynthetic pigment content}

The variations in chlorophyll pigments observed in the tree species located in the polluted and control sites are presented in Table 2 . The photosynthetic pigments in the leaves of all the four tree species at the polluted site were lower and significantly different from those at the control site except for Carotenoid contents in Ficus platyphylla and Polyalthia longifolia $(p<0.05)$. There was a reduction of chlorophyll ' $a$ ' content at polluted sites as compared to the control site as follows: Polyalthia longifolia $43.48 \%$, Mangifera indica $39 \%$ and Ficus Platyphylla $36.39 \%$. The percentage reduction of chlorophyll ' $b$ ' content in the leaves of the studied tree species is in this order: Ficus Platyphylla $63.23 \%$, Polyalthia longifolia $46.51 \%$, Terminalia catappa $39.13 \%$ and Mangifera indica, $35.85 \%$ (Table 2). A reduction in total chlorophyll content in the samples from polluted sites was observed with Polyalthia longifolia having $47.42 \%$ reduction, Mangifera indica, a decrease of $35.85 \%$, Terminalia catappa having $33.88 \%$ reduction, Ficus Platyphylla $21.05 \%$. Similarly reductions of $23.53 \%, 21.05 \%$ and $16.67 \%$ in the concentration of carotenoid pigment in the Ficus Platyphylla, Polyalthia longifolia, Terminalia catappa and Mangifera indica leaf samples from polluted were recorded (Table 2).

The changes in the assimilation of pigments of selected tree species that are exposed to vehicular air pollution in Kumasi Metropolis are presented in Table 3. In the Polyalthia longifolia, Ficus Platyphylla and Terminalia catappa leaf samples collected at the polluted site, the chlorophyll $a / b$ ratio was higher at the polluted site except for Mangifera indica, which recorded a higher chlorophyll $a / b$ ratio (1.87) at the control. $\mathrm{Chl}$ $a+b+$ carotenoid ratio of Polyalthia longifolia, Ficus Platyphylla and Terminalia catappa, was decreased at the polluted sites relative to the control site. Thus, at the polluted site there was also lower chlorophyll $(a+b)$ /carotenoid ratio for Polyalthia longifolia, Terminalia catappa, Mangifera indica and Ficus Platyphylla.
Table 1 Ambient air quality at the sampling sites during the study period

\begin{tabular}{|c|c|c|c|c|c|c|}
\hline \multirow[t]{2}{*}{ Sampling sites } & \multicolumn{6}{|l|}{ Parameter } \\
\hline & $\mathrm{CO}(\mathrm{ppm})$ & $\mathrm{SO}_{2}(\mathrm{ppm})$ & $\mathrm{NO}_{2}(\mathrm{ppm})$ & VOC (ppm) & Temperature $\left({ }^{\circ} \mathrm{C}\right)$ & Relative humidity \\
\hline Control & 0.85 & 0.07 & 0.06 & 0.01 & 35.12 & 52.40 \\
\hline Polluted & 6.68 & 0.19 & 0.09 & 0.09 & 35.90 & 51.51 \\
\hline$\%$ Increase & 87.28 & 171.43 & 33.33 & 88.89 & 2.17 & -1.70 \\
\hline
\end{tabular}

$(-)=$ Values indicate that value of control site is higher than polluted site 
Table 2 Changes in the photosynthetic pigment contents of selected tree species exposed to vehicular air pollution in Kumasi Metropolis

\begin{tabular}{|c|c|c|c|c|c|c|c|c|c|}
\hline \multirow[t]{2}{*}{ Tree species } & \multicolumn{9}{|c|}{ Photosynthetic pigments } \\
\hline & Sampling sites & $\begin{array}{l}\text { Chlorophyll ' } a \text { ' } \\
\text { (mg/g) }\end{array}$ & $p$ value & $\begin{array}{l}\text { Chlorophyll 'b' } \\
\text { (mg/g) }\end{array}$ & $p$ value & $\begin{array}{l}\text { Total } \\
\text { chlorophyll } \\
(\mathrm{mg} / \mathrm{g})\end{array}$ & $p$ value & $\begin{array}{l}\text { Carotenoid } \\
\text { content } \\
(\mathrm{mg} / \mathrm{g})\end{array}$ & $p$ value \\
\hline \multirow{3}{*}{$\begin{array}{l}\text { Terminalia cat- } \\
\quad \text { appa }\end{array}$} & Control & $0.75 \pm 0.02$ & $0.036^{*}$ & $0.46 \pm 0.00$ & $0.154^{*}$ & $1.21 \pm 0.02$ & $0.045^{*}$ & $0.19 \pm 0.01$ & $0.035^{*}$ \\
\hline & Polluted & $0.52 \pm 0.07$ & & $0.28 \pm 0.08$ & & $0.80 \pm 0.14$ & & $0.13 \pm 0.02$ & \\
\hline & $\% \mathrm{R}$ & 30.70 & & 39.13 & & 33.88 & & 31.58 & \\
\hline \multirow[t]{3}{*}{ Mangifera indica } & Control & $1.00 \pm 0.01$ & $0.042^{*}$ & $0.53 \pm 0.00$ & $0.059^{*}$ & $1.53 \pm 0.02$ & $0.048^{*}$ & $0.17 \pm 0.01$ & $0.050^{*}$ \\
\hline & Polluted & $0.61 \pm 0.09$ & & $0.34 \pm 0.05$ & & $0.94 \pm 0.14$ & & $0.13 \pm 0.01$ & \\
\hline & $\% \mathrm{R}$ & 39.00 & & 35.85 & & 38.56 & & 23.53 & \\
\hline \multirow[t]{3}{*}{ Ficus platyphylla } & Control & $0.84 \pm 0.01$ & $0.075^{* *}$ & $0.68 \pm 0.01$ & $0.000^{*}$ & $1.52 \pm 0.01$ & $0.017^{*}$ & $0.19 \pm 0.01$ & $0.008^{*}$ \\
\hline & Polluted & $0.53 \pm 0.11$ & & $0.25 \pm 0.04$ & & $0.77 \pm 0.10$ & & $0.15 \pm 0.02$ & \\
\hline & $\% \mathrm{R}$ & 36.91 & & 63.23 & & 49.34 & & 21.05 & \\
\hline \multirow{3}{*}{$\begin{array}{l}\text { Polyalthia longi- } \\
\text { folia }\end{array}$} & Control & $0.92 \pm 0.01$ & $0.022^{*}$ & $0.48 \pm 0.01$ & $0.000^{*}$ & $1.41 \pm 0.00$ & $0.003^{*}$ & $0.18 \pm 0.02$ & $0.205^{* *}$ \\
\hline & Polluted & $0.52 \pm 0.11$ & & $0.23 \pm 0.01$ & & $0.74 \pm 0.10$ & & $0.15 \pm 0.01$ & \\
\hline & $\% \mathrm{R}$ & 43.48 & & 46.51 & & 47.42 & & 16.67 & \\
\hline
\end{tabular}

${ }^{*}=$ significant different, ${ }^{* *}=$ not significantly different, $p=$ probability value, $\% R=$ percentage reduction

Table 3 Changes in assimilating pigments of selected tree species exposed to vehicular air pollution in Kumasi Metropolis

\begin{tabular}{|c|c|c|c|c|c|c|}
\hline \multirow[t]{2}{*}{ Tree species } & \multicolumn{2}{|c|}{$\mathrm{Chl} a / b$ ratio } & \multicolumn{2}{|c|}{$\begin{array}{l}\text { Chl'a' } a^{\prime}+\mathrm{Chl}^{\prime} b^{\prime}+\text { Carot- } \\
\text { enoid }\end{array}$} & \multicolumn{2}{|c|}{ Chl $(a+b) /$ Carotenoid } \\
\hline & Control & Polluted & Control & Polluted & Control & Polluted \\
\hline Terminalia catappa & 1.67 & 1.86 & 1.4 & 0.93 & 6.37 & 6.15 \\
\hline Mangifera indica & 1.87 & 1.79 & 1.69 & 1.08 & 8.94 & 7.31 \\
\hline Ficus platyphylla & 1.24 & 2.12 & 1.71 & 0.93 & 8.00 & 5.20 \\
\hline Polyalthia longifolia & 1.92 & 2.26 & 1.58 & 0.90 & 7.78 & 5.00 \\
\hline
\end{tabular}

\subsection{Heavy metal contents}

The variations in heavy metal concentration (Mean $+\mathrm{SE}$, $\mathrm{mg} / \mathrm{kg}$ ) and metal accumulation index (MAl) of leaves sample from different sampling locations are presented in Table 4. The heavy metal content in the leaves of all the four tree species at the polluted site was higher and significantly different from those at the control site $(p<0.05)$.

\subsection{Lead}

$\mathrm{Pb}$ accumulations at the control site ranged between $1.28 \pm 0.01$ and $1.78 \pm 0.01$ (Table 4). Pb accumulation $(4.68 \pm 0.02)$ was highest in Polyalthia longifolia followed by Mangifera indica, Terminalia catappa and Ficus platyphylla. At the polluted site, the maximum increase in $\mathrm{Pb}$ accumulation was observed in Polyalthia longifolia (265.63\%); it was followed by Ficus platyphylla. There was a significant difference in the $\mathrm{Pb}$ accumulation of tree species between the polluted sites and the control $(p<0.05)$.

\subsection{Copper}

Copper accumulations ranged between $5.90 \pm 0.00$ and $7.23 \pm 0.01$ in the control site (Table 4). The maximum $\mathrm{Cu}$ amounts were found in Polyalthia longifolia $(24.00 \pm 0.00 \mu \mathrm{g} / \mathrm{g})$ leaves in the polluted site and the lowest $\mathrm{Cu}$ accumulation $5.90 \pm 0.00$ ) detected in Mangifera indica in the control site. Even though the highest Cu accumulations were found in Polyalthia longifolia, the accumulation of $\mathrm{Cu}$ in F. platyphylla was higher (123.97\%) than the control site. It was followed by M. indica (123.39\%) and T.catappa (120.06\%). It was also observed that statically significant increases were found in all the tree species between the polluted sites and the control $(P<0.05)$.

\subsection{Cadmium}

Cadmium accumulation of leaf samples obtained at the control site ranged from $0.03 \pm 0.01$ to $0.13 \pm 0.01$ (Table 4). The highest $\mathrm{Cd}$ accumulations in all tree species were found in polluted sites. Among the studied tree species, Polyalthia longifolia accumulated the highest $\mathrm{Cd}$ 
Table 4 Heavy metal concentration (mean $+\mathrm{SD}, \mathrm{mg} / \mathrm{kg}$ ) and metal accumulation index (MAl) of leaves sample from different sampling locations

\begin{tabular}{|c|c|c|c|c|c|c|c|c|c|c|}
\hline \multirow[t]{2}{*}{ Tree species } & \multicolumn{9}{|l|}{ Heavy metal } & \multirow[t]{2}{*}{ MAI } \\
\hline & Sampling sites & $\mathrm{Pb}$ & $p$ value & $\mathrm{Cu}$ & $p$ value & $\mathrm{Cd}$ & $p$ value & $\mathrm{Zn}$ & $p$ value & \\
\hline \multirow[t]{3}{*}{ Terminalia catappa } & Control & $1.78 \pm 0.68$ & $0.000^{*}$ & $6.53 \pm 3.08^{\mathrm{a}}$ & $0.000^{*}$ & $0.13 \pm 0.07^{\mathrm{a}}$ & $0.000^{*}$ & $0.56 \pm 0.44^{a}$ & $0.254^{*}$ & 1.97 \\
\hline & Polluted & $3.21 \pm 1.01$ & & $14.37 \pm 5.04^{b}$ & & $1.08 \pm 0.55^{\mathrm{b}}$ & & $1.96 \pm 0.85^{\mathrm{a}}$ & & 2.58 \\
\hline & $\% \mathrm{~V}$ & 80.34 & & 120.06 & & 369.56 & & 71.43 & & \\
\hline \multirow[t]{3}{*}{ Mangifera indica } & Control & $1.75 \pm 0.00$ & $0.000^{*}$ & $5.90 \pm 0.00$ & $0.000^{*}$ & $0.05 \pm 0.02$ & $0.000^{*}$ & $0.06 \pm 0.04$ & $0.000^{*}$ & 2.9 \\
\hline & Polluted & $3.41 \pm 1.03$ & & $13.18 \pm 4.03$ & & $0.21 \pm 0.08$ & & $1.46 \pm 0.12$ & & 5.35 \\
\hline & $\% \mathrm{~V}$ & 54.20 & & 123.39 & & 320 & & 2333.33 & & \\
\hline \multirow[t]{3}{*}{ Ficus platyphylla } & Control & $1.60 \pm 0.40^{\mathrm{a}}$ & $0.000^{*}$ & $7.05 \pm 3.00$ & $0.000^{*}$ & $0.03 \pm 0.00$ & $0.001^{*}$ & $0.05 \pm 0.01$ & $0.001^{*}$ & 2.85 \\
\hline & Polluted & $3.02 \pm 0.98^{b}$ & & $15.79 \pm 4.01$ & & $0.28 \pm 0.00$ & & $0.74 \pm 0.12$ & & 3.37 \\
\hline & $\% \mathrm{~V}$ & 88.75 & & 123.97 & & 833.33 & & 1380 & & \\
\hline \multirow[t]{3}{*}{ Polyalthia longifolia } & Control & $1.28 \pm 1.00$ & $0.000^{*}$ & $7.23 \pm 3.03$ & $0.000^{*}$ & $0.05 \pm 0.03^{\mathrm{a}}$ & $0.000^{*}$ & $0.07 \pm 0.02$ & $0.007^{*}$ & 2.21 \\
\hline & Polluted & $4.68 \pm 1.04$ & & $24.00 \pm 7.00$ & & $0.23 \pm 0.10$ & & $1.18 \pm 0.16$ & & 4.30 \\
\hline & $\% \mathrm{~V}$ & 265.63 & & 93.64 & & 360 & & 1585.71 & & \\
\hline
\end{tabular}

Mean \pm SE in the same column with different letters in superscript are significantly different $(p<0.05)$

* = significantly different; $p=$ probability value; $\%$ V = percentage variation

polluted site. The $C d$ values reported in this study were lower than that of $\mathrm{Cd}$ values of plant leaves in the polluted localities of Antakya [13]. Compared with control, the highest increment in $\mathrm{Cd}$ (833.33\%) was found in $\mathrm{F}$. platyphylla (Table 4$)$. Cd content showed statically significant difference $(p<0.05)$ between the polluted and control sites in all the tree species (Table 4).

\subsection{Zinc}

$\mathrm{Zn}$ contents at the control site ranged between $0.05 \pm 0.00$ and $0.56 \pm 0.26$ (Table 4). The highest $\mathrm{Zn}$ amounts were found in T.catappa $(1.96 \pm 0.90)$ leaves in the polluted site and the lowest $\mathrm{Zn}$ accumulation $(0.05 \pm 0.00)$ detected in Ficus platyphylla in the control site. The highest $\mathrm{Zn}$ accumulations were found in Terminalia catappa. However, the accumulation of $\mathrm{Zn}$ in $M$. indica was higher (2333.33\%) than the control site. It was followed by Polyalthia longifolia (1585.71\%) and Ficus platyphylla (1380\%). In the polluted site, there were significant $(p \leq 0.05)$ increases in the other tree species except for Terminalia catappa.

\subsection{Metal accumulation index (MAI)}

Metal accumulation index value of $\mathbf{5 . 3 5}$ was highest in Mangifera indica at the polluted site followed by Polyalthia longifolia (4.30) (Table 4), while at the control site, Mangifera indica also recorded highest MAI value of
2.9 and the least MAI value of 1.97 found in Terminalia catappa.

\subsection{Relationship between photosynthetic pigments and heavy metal concentrations}

Total chlorophyll content showed a high negative correlation with the concentrations of $\mathrm{Pb}, \mathrm{Cu}$ and $\mathrm{Cd}$ in the leaves of T. catappa and also very highly negative correlation with $\mathrm{Pb}, \mathrm{Cd}$ and $\mathrm{Zn}$ concentration in Mangifera indica except for $\mathrm{Cu}$. It was also observed that total chlorophyll content had a very high negative correlation with $\mathrm{Pb}, \mathrm{Cu}$ and $\mathrm{Cd}$ concentrations in F. platyphylla and P. longifolia except for Zn (Table 5).

Carotenoid content showed high negative correlation with $\mathrm{Pb}, \mathrm{Cu}$ and $\mathrm{Cd}$ concentrations in the leaves of in $T$. catappa and very high negative correlation with $\mathrm{Pb}, \mathrm{Cu}$ and $\mathrm{Cd}$ contents in Ficus platyphylla. Carotenoid content did not reveal any relationship with $\mathrm{Pb}, \mathrm{Cu}, \mathrm{Zn}$ and $\mathrm{Cd}$ accumulation in P. longifolia and Mangifera indica (except for $\mathrm{Pb}$ ) (Table 5 .

It was observed that the concentrations of $\mathrm{Pb}$ and $\mathrm{Cu}$, as well as for $\mathrm{Pb}$ and $\mathrm{Cd}$, were positively correlated in Ficus platyphylla, Polyalthia longifolia, Terminalia catappa and Mangifera indica, while $\mathrm{Pb}$ and $\mathrm{Zn}$ concentrations were positively correlated for all species but Terminalia catappa (Table 5).

The concentrations of $\mathrm{Cu}$ and $\mathrm{Cd}$ were also positively correlated in Mangifera indica, Terminalia catappa, Polyalthia longifolia and Ficus platyphylla and were positively correlated. Also there was a positive correlation between $\mathrm{Cu}$ and $\mathrm{Zn}$ contents in Polyalthia longifolia, Mangifera 
Table 5 Relationship among metal-metal and metalphotosynthetic pigments in studied tree species under vehicular pollution

\begin{tabular}{lllll}
\hline & Terminalia catappa & Mangifera indica & Ficus platyphylla & Polyalthia longifolia \\
\hline \multicolumn{2}{l}{ Metal-metal correlations } & & & \\
$\mathrm{Pb} \times \mathrm{Cu}$ & $0.999^{* *}$ & $1.000^{* *}$ & $1.00^{* *}$ & $1.00^{* *}$ \\
$\mathrm{~Pb} \times \mathrm{Cd}$ & $0.999^{* *}$ & $0.993^{* *}$ & $0.997^{* *}$ & $0.983^{* *}$ \\
$\mathrm{~Pb} \times \mathrm{Zn}$ & & $0.996^{* *}$ & $0.970^{* *}$ & $0.987^{* *}$ \\
$\mathrm{Cu} \times \mathrm{Cd}$ & $0.992^{* *}$ & $0.997^{* *}$ & $0.982^{* *}$ \\
$\mathrm{Cu} \times \mathrm{Zn}$ & $0.999^{* *}$ & $0.995^{* *}$ & $0.971^{* *}$ & $0.985^{* *}$ \\
$\mathrm{Cd} \times \mathrm{Zn}$ & & $0.995^{* *}$ & $0.967^{* *}$ & $0.971^{* *}$ \\
$\mathrm{Metal}-$ photosynthetic pigments correlations & & \\
$\mathrm{Pb} \times$ Total Chl & $-0.820^{*}$ & $-0.910^{*}$ & $-0.966^{* *}$ & $-0.950^{* *}$ \\
$\mathrm{Cu} \times$ Total Chl & $-0.823^{*}$ & -0.907 & $-0.965^{* *}$ & $-0.954^{* *}$ \\
$\mathrm{Cd} \times$ Total Chl & $-0.838^{*}$ & $-0.925^{*}$ & $-0.963^{* *}$ & $-0.937^{* *}$ \\
$\mathrm{Zn} \times$ Total Chl & & $-0.910^{*}$ & $-0.899^{*}$ & $-0.899^{*}$ \\
$\mathrm{~Pb} \times$ Carotenoid & $-0.844^{*}$ & $-0.847^{*}$ & $-0.926^{* *}$ & \\
$\mathrm{Cu} \times$ Carotenoid & $-0.843^{*}$ & & $-0.926^{* *}$ & \\
$\mathrm{Cd} \times$ Carotenoid & $-0.857^{*}$ & & $-0.935^{* *}$ & \\
$\mathrm{Zn} \times$ Carotenoid & & & $-0.862^{*}$ & \\
\hline
\end{tabular}

indica and Ficus platyphylla. In all tree species with the exception of Terminalia catappa, significant positive correlations were found between $\mathrm{Cd}$ and $\mathrm{Zn}$ concentrations (Table 5).

\section{Discussion}

The conditions recorded in both sampling sites were not different and, therefore, did not affect the results of the photosynthetic pigments and metal concentrations in the leaves. Thus, differences observed here are to a large extent related to the distinct exposure to vehicular pollution.

The accumulation of heavy metal has also been stated to be directly related to the air entering the stomata and the amount of heavy metal taken into the leaf. These contaminants may affect the photosynthesis in plants [73]. Analysis of chlorophyll is a powerful tool for determining the effect of air pollution on plants as it plays a significant role in plant metabolism and any reduction of chlorophyll content is closely associated with plant growth [86]. Hence, the quantity of chlorophyll in the leaf and carotenoids should have valuable physiological information. The chlorophyll pigments experience certain photochemical reactions, namely: oxidation, reduction, phaeophytinization and reversible bleaching during stress condition as the pigment exists in a highly organized condition $[62,74]$. There have been significant changes in the concentration of the studied tree species photosynthetic pigments that have resulted in the reduction of chlorophyll ' $a$,' chlorophyll ' $b$ ' and total chlorophyll content in the polluted sites. This reduction in plant pigments is independent from local climate conditions and most likely due to the high vehicular pollution found in the polluted site. Such findings are consistent with the results of $[21,22,26]$ but contrary to Mukherjee and Agrawal [47] whose result indicates an increased in the content of $\mathrm{Chl} a$ and $\mathrm{Chl} b$ with a rise in air pollution load in the concentrations of $M$. indica and $P$. longifolia. In $M$. indica, elevated total chlorophyll content was also found at higher pollution loads by [80]. Chlorophyll ' $a$ ' was higher in this study than chlorophyll ' $b$.' This result is similar to [87], who reported lower values of chlorophyll ' $a$ ' than chlorophyll ' $b$ ' in Quercus petraea polluted woodland with $\mathrm{SO}_{2}$. Nayak et al. [51] reported a greater decrease in chlorophyll ' $b$ ' than chlorophyll ' $a$ ' and in some cases similar decrease in chlorophyll ' $a$ ' and chlorophyll ' $b$.' Chlorophyll pigment oxidation may also be induced by the activity of $\mathrm{SO}_{2}$ and $\mathrm{NO}_{2}$ on the chlorophyll metabolism [38], all of which are components of automotive pollution. The decrease of the active photosynthetic leaf region arising from deposits of particulate matter and visible injury symptoms on the leaves of the studied tree species may be another explanation for decreased chlorophyll content [75]. Mondal et al. [45] observed that air pollutants penetrate the leaves through the stomata, resulting in partial chloroplast denaturation and reduction of pigment content in the leaves of polluted sites. These researchers attributed this to the replacement of $\mathrm{Mg}^{2+}$ with two atoms of hydrogen and the degradation of chlorophyll to phaeophytin.

Carotenoid plays an important role in the photosynthetic process and protects chlorophyll from photoxidative reaction. In this study the amount of carotenoid was reduced compared to the control. Other studies obtained similar results [17, 21, 22, 26, 30]. Swami et al. 
[78] recorded a major decrease in carotenoid content from Shorea robusta and Mallotus phillipinensis due to roadside pollution from vehicles. Agrawal [3] also reported a decrease in the carotenoid content of various plants due to gaseous pollutant exposure. Singh and Pal [76] also reported the low carotenoid content in roadside plant species due to the accumulation of dust particles on the leaf surface as compared to the control site. Our finding, however, was inconsistent with [47], who reported significant increases in carotenoid content in parks with higher pollution loads across all plant species.

Chlorophyll ' $a$ ' is found in the pigment antenna and in photosystem I and II reaction centers, while Chlorophyll ' $b$ ' originates entirely in the pigment antenna system. Consequently, an enlargement of the PS II antenna system leads to a reduction of the Chlorophyll $a / b$ ratio [80]. Chlorophyll $a / b$ ratio provides a degree of tree tolerance index, and higher plant species typically produce more Chlorophyll ' $a$ ' than Chlorophyll ' $b$ ' [85]. A high ratio is an indication of better air pollution tolerance, and the low ratio indicates sensitivity [34]. A higher ratio of chlorophyll $a / b$ in the Polyalthia longifolia, Ficus Platyphylla and Terminalia catappa leaf samples collected at the polluted site suggests that these tree species are more tolerant to vehicular air pollution, while Mangifera indica is more sensitive to vehicular pollutants. Mukherjee and Agrawal [47] recorded a decreased ratio of Chlorophyll $a / b$ in all other species, except for P. guajava in areas with higher pollution loads.

The weight ratio of Chlorophyll $\mathrm{a}$ and $\mathrm{b}$ to carotenoids $(a+b) /(x+c)$ is one measure of greenness of plant. The lower values of $(a+b) /(x+c)$ ratio are an indicator of senescence, stress and damage to the photosynthetic system indicated by a faster chlorophyll breakdown than carotenoids. A decrease in these ratios is an indicator of the stress and harm caused by air contaminants in automobiles.

$\mathrm{Pb}$ natural, normal and toxic limits are 3, 10 and $30-300 \mathrm{mg} / \mathrm{kg}$, respectively, for plants [5, 28, 33]. Pb accumulation in the leaf samples of T. catappa, M. indica, Ficus platyphylla and $P$. longifolia trees collected from the polluted site was higher than the natural limits in plants. The highest lead content in leaf of the studied tree species was observed at the polluted sites. Similar results were obtained by $[2,7,17,37,41,50,66]$. The translocation of $\mathrm{Pb}$ from the root of plants is not the main path for the uptake of $\mathrm{Pb}$; however, plants can easily pick up $\mathrm{Pb}$ from the atmosphere through the leaves $[29,83]$. Also, [67] stated that the high $\mathrm{Pb}$ value in plants was due to the uptake from the above-ground parts (leaves stem and seeds) due to air-borne $\mathrm{Pb}$. It has been reported that an increase in lead content in the atmosphere occurs due to anthropogenic behavior, primarily due to the past combustion of leaded fuel, and the persistence of $\mathrm{Pb}$ in the environment. Lead has also been considered as one of the most distinctive heavy metals attributable to vehicular pollution $[59,77] . \mathrm{Pb}$ is one of the most common elements in polluted areas; excessive lead produces detrimental effects on plant morphology, development and photosynthetic processes $[10,60]$.

$\mathrm{Cu}$ is a micronutrient related to the growth process in plant tissue, but it is toxic when it is in excess concentration. According to 75, 59 most plant species can accumulate substantial amounts of copper under different natural and anthropogenic conditions. The phytotoxic level is $30 \mathrm{ppm}$, while the acceptable limit of copper for plants is between 2 and 20 ppm $[28,54]$. In this study, Cu concentrations were within the acceptable limits, but higher in the polluted sites. The high concentrations of $\mathrm{Cu}$ at polluted sites could be caused by corrosion of metal parts of cars derived from engine wear, brushing and metal bearing [4]. Similar result was obtained by [17, 25 and 66].

Among other metals in this study, cadmium had the lowest concentrations. According to Hu et al. [25], Cd puts up in low concentrations in particulate matter, thus the likelihood of low $\mathrm{Cd}$ concentrations in the plant samples. The amount of $\mathrm{Cd}$ in all the studied tree species at polluted and control sites was lower than the acceptable limit levels of $\mathrm{Cd}\left(>10 \mu \mathrm{g} \mathrm{g}^{-1}\right)$ in plants $[43,81]$, except for Terminalia catappa that exceeded the maximum toxic level of $0.5 \mu \mathrm{g} \mathrm{g}-1$ for plant foods [46], an indication that it is not safe for its usage for medicinal purposes. Liu et al. [40] stated that fossil fuels combustion, vehicle tire wear and vehicle lubrication oil, and combustion are the main sources of airborne $\mathrm{Cd}$ to the environment.

Zinc is a vital constituent of plant protein that performs an essential function in biosynthesis [69]. Zinc originates mostly from atmospheric deposition; it may also be obtained from traffic [16]. The acceptable levels of Zinc in plant have the ranges between 10 and $150 \mathrm{mg} / \mathrm{kg}$ [54]. It was also observed that $\mathrm{Zn}$ increases were found in the other tree species in the polluted site compared to control except for Terminalia catappa. Our result agrees with [25] report of an increased $\mathrm{Zn}$ concentration in polluted sites. In their study, the highest $Z n$ concentration was contained in S. matsudana from the polluted site, while the minimal concentration was observed in $F$. chinensis of the control. Similarly, [17] reported elevated $\mathrm{Zn}$ accumulation in leaf tissues of all plant species the polluted localities in Antakya region in comparison with the control. Bargagli [8] recorded an increase in the concentration of zinc by Populus at the urban areas than in the control sites. Studies have shown that trees which accumulate $\mathrm{Cd}$ do not accumulate $\mathrm{Zn}[17,65]$. Our result is in agreement with this assertion; hence, zinc accumulation in all the studied tree species was higher than the cadmium in the studied sites. The microclimate factors (temperature and humidity) to a very large extent affect the pollutant process for on 
road vehicles [68]. Higher relative humidity brings about lower concentrations of air pollutants such as $\mathrm{NOx}, \mathrm{SO}_{2}$, $\mathrm{HC}$ and particulate matter [39]. The concentration of air pollution may also vary according to the local temperatures, as air quality decreases as temperature increases. Studies have shown that emissions significantly increase above 2.25 ppm under high temperature [20]. However, this effect is not expected to bias the results presented in this study as local climate conditions are rather similar between control and polluted sites.

Significant relationships were also observed between the concentrations of different metals in the leaves and between their concentrations and the content of photosynthetic pigments. This relationship may have accounted for the metal-specific effects on the chlorophyll and carotenoid biosynthesis [55]. There is simultaneous accumulation of different elements in the leaves of plant species [40]. Metal accumulation index relies upon different factors such as atmospheric chemistry of the local environment and meterology [25], including height of the sampled trees, sampling time and plant characteristics $[24,89]$. In this study the MAI value (5.35) was highest in Mangifera indica at the polluted site followed by Polyalthia longifolia (4.30) (Table 5). There were changes in MAI in all the studied tree species resulting from different pollution burden and an indication that the removal capabilities of plant species differ from each other [31]. This result agrees with Liu et al. [40], report of higher MAI values of plant species collected from the distance of 1-9 $\mathrm{m}$ from the road, while the plant species obtained from $10 \mathrm{~m}$ had lower MAI values. Similarly, maximum MAI values were recorded at the Barjora forest surrounded by different pollution zones and minimum MAI values at a Wildlife Sanctuary in West Bengal, India, a control site without human activities. Hu et al. [25] also reported elevated metal accumulation index values at Yan'an, China. In the present study, the maximum MAI value found in Mangifera indica (5.35) and Polyalthia longifolia (4.30) reveals that they possess good accumulation in heavy metal when growing in a polluted condition. Thus, it could be used as buffer between contaminated and susceptible areas $[25,31,48]$. Owing to the complexities of the parameters of environment it has been challenging to calculate harmful concentrations and the effects of heavy metals in natural ecosystems [81]. Deposition of heavy metal and translocation occurs in plants via the roots and leaves $[29,69]$, so the precise quantity of elements from air or soil is impossible to differentiate. It is evident that plants in polluted areas are rich in heavy metals relative to plants in stable conditions by comparing the results of the control site and others, independent of the absorption process [25].

\section{Conclusion}

This study established that the studied tree species situated at the polluted sites (arterial roadsides) were negatively affected by higher vehicular air pollutant concentrations as compared to the control. A higher ratio of chlorophyll $a / b$ in the Ficus Platyphylla, Polyalthia longifolia and Terminalia catappa leaf samples collected the polluted site suggests that these tree species are more tolerant to vehicular air pollution, while Mangifera indica is more sensitive to vehicular pollutants. A higher metal accumulation index value found in Mangifera indica and Polyalthia longifolia reveals that they possess good accumulation in heavy metal while growing in polluted environments. The usage of urban trees as bioindicators is a cost-effective and simple strategy and thus provides a sustainable ecological method for the conservation of urban habitats.

Acknowledgements We acknowledge Kwame Nkrumah University of Science and Technology Kumasi, Ghana, for making available their laboratory facilities. We would like to thank the anonymous reviewers for for critically reading the manuscript, comments and suggestions.

Author contributions UNU and EJD designed the experiment. UNU carried out the experiment, analyzed the data and drafted the manuscript. EJD and FAE revised and reviewed the draft manuscript. All authors read and approved the final manuscript.

Funding The authors self-funded the study.

Availability of data and materials All the data obtained during the study are presented in this manuscript. Any further enquiries for additional information are available upon request from the corresponding author.

\section{Compliance with ethical standards}

Conflict of interest The authors declare that they have no conflict of interest.

Open Access This article is licensed under a Creative Commons Attribution 4.0 International License, which permits use, sharing, adaptation, distribution and reproduction in any medium or format, as long as you give appropriate credit to the original author(s) and the source, provide a link to the Creative Commons licence, and indicate if changes were made. The images or other third party material in this article are included in the article's Creative Commons licence, unless indicated otherwise in a credit line to the material. If material is not included in the article's Creative Commons licence and your intended use is not permitted by statutory regulation or exceeds the permitted use, you will need to obtain permission directly from the copyright holder. To view a copy of this licence, visit http://creativecommons .org/licenses/by/4.0/. 


\section{References}

1. Adarkwa KK (2011) The role of Kumasi in national development-Kumasi as a central place. In: Adarkwa KK (ed) Future of the tree: towards growth and development of Kumasi. University Printing Press, Kumasi, pp 14-34

2. Agrahari P, Richa SK, Rai S, Singh VK, Singh DK (2018) Ficus religiosa tree leaves as bioindicators of heavy metals in Gorakhpur City, Uttar Pradesh. India Pharmacog J 10(3):416-420

3. Agrawal $\mathrm{M}$ (1985) Plant factor as indicator of $\mathrm{SO}_{2}$ and $\mathrm{O}_{3}$ pollutants. In: Proc. international symposium on biological monitoring of the state of environment (bio-indicators). Indian National Science Academy, New Delhi, pp 225-231

4. Agyemang-Bonsu KW, Dontwi IK, Tutu-Benefoh DA, Bentil DE, Boateng OG, Asuobonteng K, Agyemang W (2010) Traffic-data driven modelling of vehicular emissions using COPERT III in Ghana: a case study of Kumasi. Am J Sci Ind Res 1(1):32-40

5. Allen SE, Grimshow HM, Parkinson JA, Quarmby C (1984) Chemical analysis of ecological materials. Blackwell, Oxford

6. Arnon DI (1949) Copper enzyme in isolated chloroplasts. Polyphenoloxidase in Beta vulgaris. Plant Physiol 24:1-15

7. Aslam M, Verma KD, Dhakerya R (2012) Bioindicator: a comparative study on uptake and accumulation of heavy metals in some plant's leaves of M.G. Road, Agra City, India. Res J Environ Earth Sci 4(12):1060-1070

8. Bargagli R (1998) Trace elements in terrestrial plants: an ecophysiological approach to biomonitoring and biorecovery. Springer, Berlin

9. Cavanagh JAE, Zawar-Reza P, Wilson JG (2009) Spatial attenuation of ambient particulate matter air pollution within an urbanised native forest patch. Urban For Urban Green 8(1):21-30

10. Cenkci S, Cigerci IH, Yildiz M, Özay C, Bozdag A, Terzi H (2010) Lead contamination reduces chlorophyll biosynthesis and genomic template stability in Brassica rapaL. Environ Exp Bot 67:467-473

11. Cetin M, Adiguzel F, Gungor S, Kaya E, Sancar MC (2019) Evaluation of thermal climatic region areas in terms of building density in urban management and planning for Burdur, Turkey. Air Qual Atmos Health 12(9):1103-1112

12. Cetin M, Onac AK, Sevik H, Sen B (2019) Temporal and regional change of some air pollution parameters in Bursa. Air Qual Atmos Health 12(3):311-316

13. Cetin M, Sevik H, Yigit N (2018) Climate type-related changes in the leaf micromorphological characters of certain landscape plants. Environ Monit Assess 190(7):404

14. Cetin M, Zeren I, Sevik H, Cakir C, Akpinar H (2018) A study on the determination of the natural park's sustainable tourism potential. Environ Monit Assess 190:167

15. Chauhan A (2010) Photosynthetic pigment changes in some selected trees induced by automobile exhaust in Dehradun. $J$ New York Sci 3(2):45-51

16. Conti ME, Pino B, Boca A (2008) Lichen Usnea barbata as a biomonitor of airborne elements deposition in the Province of Tierra del Fuego (southern Patagonia, Argentina). Ecotoxicol Environ Saf 72:1082-1089

17. Doganlar ZB, Atmaca M (2011) Influence of airborne pollution on $\mathrm{Cd}, \mathrm{Zn}, \mathrm{Pb}, \mathrm{Cu}$, and $\mathrm{Al}$ accumulation and physiological parameters of plant leaves in Antakya (Turkey). Water Air Soil Pollut 214:509-523

18. Dwivedi AK, Tripathi BD (2007) Pollution tolerance and distribution pattern of plants in surrounding area of coal-fired industries. J Environ Biol 28:257-263

19. Dzierżanowski K, Popek R, Gawrońska H, Sæbø A, Gawroński SW (2011) Deposition of particulate matter of different size fractions on leaf surfaces and in waxes of urban forest species. Int J Phytoremediation 13:1037-1046

20. Gingrich JW, Callahan TJ, Dodge LG (2003) Humidity and temperature correction factors for no $\mathrm{X}$ emissions from spark ignited engines. Southwest Research Institute San Antonio, Houston, Detroit, Washington, DC

21. Giri S, Shrivastava D, Deshmukh K, Dubey P (2013) Effect of air pollution on chlorophyll content of leaves. Curr Agric Res J 1(2):93-98

22. Govindaraju MRS, Ganeshkumar P, Suganthi V, Muthukumaran $\mathrm{R}$, Visvanathan $\mathrm{P}$ (2010) Impact assessment of air pollution stress on plant species through biochemical estimations. World Acad Sci Eng Technol 4:784-787

23. Gupta S, Nayek S, Bhattacharya P (2011) Effect of air-borne heavy metals on the biochemical signature of tree species in an industrial region, with an emphasis on anticipated performance index. Chem Eco 27(4):381-392

24. Hofman J, Stokkaer I, Snauwaert L, Samson R (2013) Spatial distribution assessment of particulate matter in an urban street canyon using biomagnetic leaf monitoring of tree crown deposited particles. Environ Pollut 183:123-132

25. Hu YN, Wang DX, Wei LJ, Song B (2014) Heavy metal contamination of urban topsoils in a typical region of Loess Plateau, China. J Soils Sediments 14:928-935

26. Joshi PC, Swami A (2009) Air pollution induced changes in the photosynthetic pigments of selected plant species. J Environ Biol 30(2):295-298

27. Kabata-Pendias A, Pendias H (1986) Trace elements in soils and plants. CRC Press INC, Boca Raton

28. Kabata-Pendias A, Piotrowska M (1984) Zanieczyszczenie gleb i Roslin Uprawnych Pierwiastkami Sladowymi. CBR-Opracowanie Problemowe, Warshawa

29. Kabata-Pendias A, Pendias H (2001) Trace elements in soils and plants. CRC Press, Boca Raton

30. Kapoor CS, Bamniya BR, Kapoor K (2012) Natural and effective control of air pollution through plants- studies on a tree species: Holoptelea integrifolia L. Mitig Adapt Strat Glob Change 17:793-803

31. Karmakar D, Padhy PK (2019) Air pollution tolerance, anticipated performance, and metal accumulation indices of plant species for greenbelt development in urban industrial area. Chemosphere 237:124522

32. Kaur M, Nagpal AK (2017) Evaluation of air pollution tolerance index and anticipated performance index of plants and their application in development of green space along the urban areas. Environ Sci Pollut Control Ser 24(23):18881-18895

33. Kloke A, Sauerbeck DC, Vetter H (1984) The contamination of plants and soils with heavy metals and the transport of metals in terrestrial food chains. In: Nriagu JO (ed) Changing metal cycles and human health. Dahlem workshop reports. Life sciences research report, vol 28. Springer, Berlin

34. Kondo N, Akiyama Y, Fujiwara M, Sugahara K (1980) Sulfite oxidizing activities in plants. Studies on the effects of air pollutants in plants and mechanism of phytotoxicity. Res Rep Nat Environ Study Jpn 11:137-150

35. Kovács M (1992) Trees as biological indicators. In: Kovacs M (ed) Biological indicators in environmental protection. Ellis Harwood, New York, p 207

36. Koz B, Cevik U, Ozdemir T, Duran C, Kaya S, Gundogduc A, Celik N (2008) Analysis of mosses along Sarp-Samsun highway in Turkey. J Hazard Mater 153:646-654

37. Kruger AL (2007) Accumulation and toxicity of lead in soil along the road verges in the city of Cape Town. M-Tech thesis, Environmental Health in the Faculty of Applied Sciences, Cape Peninsula University of Technology, pp 18-102 
38. Lauenorth WK, Dodd JL (1981) Chlorophyll reduction in western wheat grass (Agropyron smithiii Rydb.) exposed to sulpher di oxide. Water Air Soil Pollut 15:309-315

39. Lindhjem C, Chan, LM, Pollack A, Kite C (2004). Applying humidity and temperature corrections to on and off-road mobile source emissions. Paper presented at the Proc. 13th Intl. Emission inventory conference

40. Liu YJ, Zhu YG, Din H (2007) Lead and cadmium in leaves of deciduous trees in Beijing, China: development of a metal accumulation index (MAI). Environ Pollut 145:387-390

41. Maddah SM, Moraghebi F (2015) Analysis of the physiological responses of the plane and willow trees against air pollution in Tehran. Iran J Plant Physiol 6(1):1579-1587

42. Manu A, Twumasi YA, Coleman TL (2006) Is it the result of global warming or urbanization? The rise in air temperature in two cities in Ghana. In: Proceedings of the 5th FIG regional conference, Accra, Ghana, 8-11 March

43. Markert B (1993) Instrumental analysis of plants. In: Markert $B$ (ed) Plants as biomonitors: indicators for heavy metals in terrestrial environment. VCII, Weinheim, pp 65-103

44. McDonald AG, Bealey WJ, Fowler D, Dragosits U, Skiba U, Smith RI, Donovan RG, Brett HE, Hewitt CN, Nemitz E (2007) Quantifying the effect of urban tree planting on concentrations and depositions of $\mathrm{PM}_{10}$ in two UK conurbations. Atmos Environ 41(38):8455-8467

45. Mondal D, Gupta S, Datta JK (2011) Anticipated performance index of some tree species considered for green belt development in an urban area. Int Res J Plant Sci 2(4):099-106

46. MPHPRC (The Ministry of Public Health of the People's Republic of China) (2012). Food pollution limit, national food safety standards, the national standards of the People's Republic of China (GB 2762-2012). 2012-11-13 released and 2013-06-01 implemented.

47. Mukherjee A, Agrawal M (2015) Pollution response score of tree species in relation to ambient air quality in an urban area. Bull Environ Contam Toxicol 96:196-202

48. NadgorskaeSocha A, Kandziora-Ciupa M, Trzesicki M, Barczyk $G$ (2017) Air pollution tolerance index and heavy metal bioaccumulation in selected plant species from urban biotopes. Chemosphere 183:471-482

49. Narwaria YS, Kush K (2012) Environmental assessment of air pollution on roadside plants species at Dehradun, Uttarakhand, India. J Environ Res Develop 7:710-714

50. Naveed NH, Batool Al, Rehman FU, Hameed U (2010) Leaves of roadside plants as bioindicator of traffic related lead pollution during different seasons in Sargodha, Pakistan. Afr J Environ Sci Technol 4(11):770-774

51. Nayak R, Biswal D, Sett R (2012) Biochemical changes in some deciduous tree species around Talcher thermal power Station, Odisha. India J Environ Biol 34:521-528

52. Owusu K (2009) Changing rainfall climatology of West Africa: implications for Rainfed Agriculture in Ghana and Water Sharing in the Volta Basin. University of Florida, Gainesville, FL, USA

53. Ozel HB, Ozel HU, Varol T (2015) Using leaves of oriental plane (Platanus orientalis $\mathrm{L}$ ) to determine the effects of heavy metal pollution caused by vehicles. Pol J Environ Stud 24(6):2569-2575

54. Padmavathiamma PK, Li LY (2007) Phytoremediation technology: hyperaccumulation metals in plants. Water Air Soil Poll 184:105-126

55. Panda SK (2003) Heavy-metal phytotoxicity induces oxidative stress in a moss Taxithellium sp. Curr Sci 84(5):631-633

56. Pathak RK, Tomar C, Neelumalviya MS (2015) Phytomonitoring of atmospheric pollution in road side perennial trees of Indore city (M. P.). Int J Adv Eng Technol 7:1727-1734
57. Petrova S, Yurukova L, Velcheva I (2014) Possibilities of using deciduous tree species in trace element biomonitoring in an urban area (Plovdiv, Bulgaria). Atmos Pollut Res 5(2):196-202

58. Petrova ST (2011) Biomonitoring study of air pollution with Betula pendula Roth., from Plovdiv, Bulgaria. Ecologia Balkanica 3(1):1-10

59. Plesničar A, Zupančič N (2005) Heavy metal contamination of roadside soil along Ljubljana-Obrežje highway. RMZ Mater Geoenvironment 52(2):403-418

60. Pourrut B, Shahid M, Dumat C, Winterton P, Pinelli E (2011) Lead uptake, toxicity, and detoxification in plants. Rev Environ Contam Toxicol 213:113-136

61. Prajapati SK, Tripathi BD (2008) Seasonal variation of leaf dust accumulation and pigment content in plant species exposed to urban particulates pollution. J Environ Qual 37:865-870

62. Puckett KJ, Nieboer E, Gorzynski MJ, Richardson DHS (1973) The uptake of metal ions by lichens: a modified ion-exchange process. N Phytol 72:329-342

63. Rai PK (2016) Biodiversity of roadside plants and their response to air pollution in an Indo-Burma hotspot region: implications for urban ecosystem restoration. J Asia Pac Biodivers 9:47-55

64. Raina AK, Aggarwal B (2004) Effect of vehicular exhaust on some trees in Jammu-II. J Ind Pollut Control 20(2):229-232

65. Reeves RD, Baker AJM (2000) Metal-accumulating plants. In: Raskin I, Ensley BD (eds) Phytoremediation of toxic metals. Wiley, NY, pp 193-229

66. Rolli NM, Gadi SB, Giraddi TP (2016) Bioindicators: study on uptake and accumulation of heavy metals in plant leaves of State Highway Road, Bagalkot, India. J Agric Ecol Res 6(1):1-8

67. Rose $M$, Knaggs $M$, Owen L, Baxter $M(2001)$ A review of analytical methods for lead, cadmium, mercury, arsenic and tin determination used in proficiency resting. J Anal Atomic Spectrom 16(9):1101-1106

68. Sandow B (2016) Diurnal rhythms of ambient air pollution due to vehicular traffic in Accra. Unpublished M.Ph Dissertation, University of Ghana, $55 \mathrm{pp}$

69. Serbula SM, Kalinovic TS, Ilic AA, Kalinovic JV, Steharnik MM (2013) Assessment of air borne heavy metal pollution using Pinus spp. and Tilia spp. Aerosol Air Qual Res 13:563-573

70. Sert EB, Musa T, Mehmet C (2019) Heavy metal accumulation in rosemary leaves and stems exposed to traffic-related pollution near Adana-İskenderun Highway (Hatay, Turkey). Environ Monit Assess 191:553

71. Sevik H, Cetin M, Ozel HB, Akarsu H, Cetin IZ (2020) Analyzing of usability of tree-rings as biomonitors for monitoring heavy metal accumulation in the atmosphere in urban area: a case study of cedar tree (Cedrus sp.). Environ Monit Assess 192:23

72. Sevik H, Cetin M, Ozel HB, Pinar B (2019a) Determining toxic metal concentration changes in landscaping plants based on some factors. Air Qual Atmos Health 12(8):983-991

73. Sevik H, Ozel HB, Cetin M, Özel HU, Erdem T (2019b) Determination of changes in heavy metal accumulation depending on plant species, plant organism, and traffic density in some landscape plants. Air Qual Atmos Health 12(2):189-195

74. Sharma AP, Tripathi BD (2009) Biochemical response in tree foliage exposed to coal-fired power plant emission in seasonally dry tropical environment. Environ Monit Assess 158:197-212

75. Singh P, Sthapak J (1999) Reduction in protein contents in a few plants as indicators of air pollution. Pollut Res 18:281-283

76. Singh P, Pal A (2017) Response of dust accumulation on roadside plant species due to open cast mining at Jhansi-Allahabad $\mathrm{NH}-76$, Uttar Pradesh, India. Trop Plant Res 4(3):461-467

77. Sutherland RA (2003) Lead ingrain size fractions of road-deposited sediment. J Environ Pollut 121:229-237 
78. Swami A, Bhatt D, Joshi PC (2004) Effect of automobile pollution on Sal(Shorea robusta)and Rohini (Mallotus phillipinesis) at Asarori, Dehradun. Him J Environ Zool 18:57-61

79. Tanhan P, Kruatrachue M, Pokethitiyook P, Chaiyarat R (2007) Uptake and accumulation of cadmium, lead and zinc by Siam weed [Chromolaena odorata (L.) King \& Robinson]. Chemosphere 68:323-329

80. Thambavani DS, Kumar RS (2011) Induced changes of photosynthetic pigments in selected plant species due to cement dust pollution. Asian J Exp Chem 6(1):8-16

81. Tomašević $M$, Rajšić $S$, Đordević $D$, Tasić $M$, Krstić J, Novaković $\checkmark$ (2004) Heavy metals accumulation in tree leaves from urban areas. Environ Chem Lett 2:151-154

82. Tripathi AK, Gautam M (2007) Biochemical parameters of plants as indicators of air pollution. J Environ Biol 28(1):127-132

83. Turer D, Maynard JB, Sansalone JJ (2001) Heavy metal contamination in soils of urban highways: comparison between runoff and soil concentrations at Cincinnati, Ohio. Water Air Soil Pollut 132(3-4):293-314

84. Turkyilmaz A, Sevik H, Cetin M (2018) The use of perennial needles as biomonitors for recently accumulated heavy metals. Landsc Ecol Eng 14(1):115-120

85. Verma A, Singh SN (2006) Biochemical and ultrastructural changes in plant foliage exposed to auto-pollution. Environ Monit Assess 120:585-602

86. Wagh ND, Shukla Poonam V, Tambe Sarika B, Ingle ST (2006) Biological monitoring of roadside plants exposed to vehicular pollution in Jalgaon city. J Environ Biol 27(2):419-421
87. Williams RJH, Lloyd MM, Ricks GR (1971) Effect of atmospheric pollution on deciduous woodland. Part 1. Some effects on leaves of Quercus petraea. (Mattuschka) Leibl. Environ Pollution 2:57-59

88. World Health Organization (2000) Biomonitoring of air quality using plants. Air hygiene report no. 10, Geneva

89. Yin S, Shen ZM, Zhou PS, Zou XD, Che SQ, Wang WH (2011) Quantifying air pollution attenuation within urban parks: an experimental approach in Shanghai, China. Environ Pollut 159:2155-2163

90. Zhang H, Zhang Y, Wang Z, Ding M, Jiang Y, Xie Z (2016) Trafficrelated metal(loid) status and uptake by dominant plants growing naturally in roadside soils in the Tibetan plateau, China. Sci Total Environ 573:915-923

91. Zhang M, Yan X, Zhang F, Zeng C, Devkota LP (2012) Factorial analysis of heavy metal concentration in roadside farmland plants around Kathmandu. Nepal Appl Mech Mater 178-181:1016-1021

Publisher's Note Springer Nature remains neutral with regard to jurisdictional claims in published maps and institutional affiliations. 